ANNA WRÓBLEWSKA-KURDYK*

LIDIA NOWAK*

KATARZYNA DANCEWICZ*

ANTONI SZUMNY**

BEATA GABRYŚ**

\title{
IN SEARCH OF BIOPESTICIDES: \\ THE EFFECT OF CARAWAY CARUM CARVI ESSENTIAL OIL AND ITS MAJOR CONSTITUENTS ON PEACH POTATO APHID MYZUS PERSICAE PROBING BEHAVIOR
}

\begin{abstract}
The application of caraway essential oil and its main components, carvone and limonene, to plant surface caused significant changes in aphid probing at the level of non-vascular tissues as well as sieve elements. On treated plants, probes were short and non-probing intervals were long, phloem phase was short and sustained sap ingestion periods occurred sporadically. The deterrent activity of caraway oil is determined mainly by the content of carvone that has the most significant impact on aphid probing behavior. The impediment of aphid probing at the pre-ingestive (pre-phloem) and/or ingestive (phloem) phases revealed the
\end{abstract}

* Department of Botany and Ecology, University of Zielona Góra, Szafrana 1, 65-516 Zielona Góra, Poland, e-mails: A.Wroblewska@wnb.uz.zgora.pl; lidka-nowak904@wp.pl; k.dancewicz@ wnb.uz.zgora.pl; b.gabrys@wnb.uz.zgora.pl

** Department of Chemistry, University of Environmental and Life Sciences in Wrocław, Norwida 25, 50-375 Wrocław, Poland, e-mail: antoni.szumny@up.wroc.pl 
passage of compounds through the plant surface and distribution within tissues in a systemic way.

Keywords: antifeedants, essential oils, caraway, Electrical Penetration Graph

\section{Introduction}

Aphids (Aphidoidea) are insects of worldwide occurrence. Many species of this group have been classified as serious pests in agriculture and horticulture, mainly due to their frequent outbreaks and high fecundity (Leszczyński 1996). Usually, they live in colonies on all plant organs but they are the most frequent on leaves and stems, especially the young ones (Cichocka 1980; Cichocka, Goszczyński 1986; Bogdanowicz et al. 2004).

In Poland, there occur approximately 700 aphid species (Bogdanowicz et al. 2004). The peach potato aphid Myzus persicae (Sulz.) is considered an important pest of almost all cultivated plants in the field as well as in the greenhouses (Dancewicz, Gabryś 2008; Dancewicz et al. 2012). M. persicae occurs all over Poland and feeds on plants of more that 40 plant families (Dancewicz, Gabryś 2008). Apart from removing vital fluids from plant sieve elements, aphids are very effective vectors of virus diseases: approximately $60 \%$ of all plant viruses are spread by these insects (Pettersson et al. 2007). According to Blackman and Eastop (1985), the peach potato aphid is able to transmit over 150 plant viruses of the 275 known ones (Nault 1997; Katis et al. 2007). The elimination or at least the reduction of penetration of plant tissues by aphid stylets may save plants from pathogen infection (Martin et al. 1997). At present, aphid control is based mainly on the use of broad spectrum insecticides. However, the negative effects of their application, e.g. toxicity, insect resistance, and lack or low level of biodegradation caused an increase in the search for the compounds of natural origin, including plant essential oils (Dancewicz et al. 2005; Koul et al. 2008; Abd-Elhady 2012; Dutka 2013). Essential oils are composed of volatile secondary plant metabolites. They may occur in all plant parts, i.e. in fruits, leaves, subterranean parts, and tree trunks (e.g. in pines). There are more than 150 known components of essential oils that have many physiological and ecological functions, for example to attract pollinators or to repel herbivores (Koul et al. 2008; Dutka 2013). Essential oils are often termed as natural pesticides. Their biological activity has 
been associated with toxic effect on various insect developmental instars, the reduction in insect fecundity, and/or repellent properties (Dutka 2013). In present and future plant protection practices, essential oils and their constituents may appear a prospective alternative to conventional pesticides (Dutka 2013).

Caraway Carum carvi L. (Apiaceae) is a common household plant grown around the world, including Poland where it covers an area of 8,000 ha (Seidler-Łożykowska et al. 2010). It is widely used to flavor foods, as addition to fragrances, and for medical preparations. Caraway fruits contain $1-7 \%$ of essential oils consisting of about 30 compounds, from which carvone and limonene account for the main portion (40-80\% and 40-50\%, respectively) (Sedlakova et al. 2003; Seidler-Łożykowska et al. 2010). Caraway oil and its major constituents have broad spectrum of biological activity. For example, caraway is one of the medicinal plants used for digestion problems, as it is known to possess anti-colitic activity (Keshavarz et al. 2013), it enhances body exposure to paracetamol in mice (Samojlik et al. 2012), and it inhibits growth of many bacteria and fungi (Seidler-Łożykowska et al. 2013). At the same time, caraway can temporally increase thyroid hormones and cause hyperthyroidism, which was demonstrated for rats (Dehghani et al. 2010). Caraway oil and its principal components, carvone and limonene, are anticarcinogenic (Zheng et al. 1992; Crowell 1999; Kaefer, Milner 2011). The application of carvone or limonene causes an increase in activity of the detoxifying enzyme GST in the liver of mice (Zheng et al. 1992). Insecticidal activity of caraway essential oil, carvone, and limonene against $\mathrm{Si}$ tophilus oryzae, S. zeamais, and Tribolium castaneum has also been reported (Abdelgaleil et al. 2009; Fang et al. 2010). Carvone is also an effective repellent to T. castaneum (Caballero-Gallardo et al. 2011). In unpublished studies by Visser (www.olfacts.com/aphid-repellents/), carvone appeared also to have repellent properties to $M$. persicae. In our previous study, we demonstrated that caraway oil deterred the settling of M. persicae on plants during a simple choice-assay as soon as 1 hour after treatment and at least until 24 hours later, which was the end of the experiment (Dancewicz et al. 2012).

The aim of the present study was to investigate the behavioral background of the settling deterrent activity of caraway essential oil. We evaluated the effect of caraway oil and its major components (carvone and limonene) on peach potato aphid behavior during probing in purpose to determine the impact of caraway-derived compounds on aphid activities in non-vascular tissues and the consumption of phloem sap. 


\section{Material and Methods}

The plant material for essential oils preparation was obtained from Svedeponic Company (Kraśnicza Wola) and from Kawon-Hurt (Krajewice). Essential oils were obtained from plant material by hydrodistillation on Derying apparatus, as described in Szumny et al. (2010). In brief, approximately $200 \mathrm{~g}$ of fresh or $50 \mathrm{~g}$ of dried plant material was placed in a 21 round flask together with $900 \mathrm{~mL}$ of distilled water. The sample flask was heated for $2 \mathrm{~h}$ after the boiling point was reached. The vapors were condensed by means of cold refrigerant. After 120 min of distillation, depending on plant material, from 0.25 to $2.5 \mathrm{ml}$ of essential oil containing the volatile compounds was collected in a $2.5 \mathrm{~mL}$ vial and kept at $-15^{\circ} \mathrm{C}$ until the biological tests were performed. Carvone and limonene (Fig. 1) were purchased from Sigma-Aldrich. Essential oil and carvone and limonene were applied as $0.1 \%$ ethanolic solutions. One leaf of a plant was immersed in a respective solution for $30 \mathrm{~s}$. and allowed to dry for 1 hour before the start of the experiments.
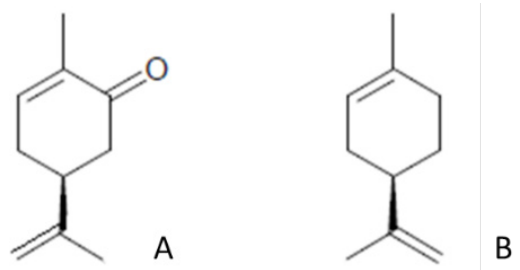

Figure 1. Major components of caraway oil: carvone (A) and limonene (B)

The laboratory rearing of $M$. persicae on Chinese cabbage Brassica rapa $\mathrm{L}$. ssp. pekinensis. Aphids and plants were reared in the laboratory at $20^{\circ} \mathrm{C}, 65 \%$ $\mathrm{RH}$, and 16:8 L:D photoperiod. The stock colonies were kept as follows: an adult aphid was placed on a plant and allowed to reproduce for 24 hours. Then the female was removed and the remaining larvae were allowed to develop. Young, 2-3 days old (i.e., 2-3 days after the final moult) viviparous apterous females were selected for experiments. The plants used in the bioassays were 5-6 weeks old.

Aphid probing was monitored using the technique of electronic registration of aphid probing in plant tissues, known as EPG (Tjallingii 1995). In this experimental set-up, aphid and plant are made parts of an electric circuit, which is completed when the aphid inserts its stylets into the plant. Weak voltage is supplied in the circuit, and all changing electric properties are recorded as EPG waveforms that can 
be correlated with aphid activities and stylet position in plant tissues (Tjallingii 2001). Aphids were attached to a golden wire electrode with conductive silver paint and starved for $1 \mathrm{~h}$ prior to the experiment. Probing behavior of 15 apterous females per studied plant/aphid combination was monitored for $8 \mathrm{~h}$ continuously with a four-channel DC-EPG recording equipment. Each aphid was given access to a freshly prepared plant: one leaf of a plant was covered with the solution of the caraway oil, its components, or a solvent (control). The plant electrode was placed in the soil. Signals were saved and analysed using the PROBE 3.1 software provided by W. F. Tjallingii (EPG-Systems, Dillenburg 126703 CJ Wageningen, The Netherlands). The following aphid activities were distinguished: no - non probing, $\mathrm{C}$ - pathway (probing in non-vascular tissues), $\mathrm{G}$ - xylem phase, $\mathrm{E}$ - phloem phase (divided into E1 and E2 that represent watery saliva secretion and sap ingestion, respectively) (Leszczyński 1996; Gabryś 2000). The parameters derived from EPGs were analyzed according to their frequency and duration in configuration related to activities in peripheral and vascular tissues. The incomplete (i.e. shorter than 8 hours) recordings were excluded from analysis. The values of EPG parameters were analyzed using Mann-Whitney U-test.

\section{Results}

The EPG recording revealed all kinds of aphid activities related to plant penetration: non-probing, pathway phase ' $\mathrm{C}$ ' including the unidentified ('derailed') stylet movements 'F', phloem watery salivation and sap ingestion 'E1' and 'E2', respectively, and xylem sap uptake 'G'. 'F' and 'G' activities occurred sporadically irrespective of a treatment.

The typical behavior of $M$. persicae on control untreated plants consisted mainly of probing activities ( $85 \%$ of experimental time), which were associated with pathway and phloem phases: $63 \%$ and $26 \%$ of the probing time, respectively (Tab. 1). Aphids typically had 26 probes of approximately 16 minutes duration, on average. Non-probing intervals between probes were relatively short, less than 3 minutes on average. There were usually four phloem phases per aphid and these phloem phases included watery salivation E1 as well as sap ingestion E2. Generally, there were two periods of sustained sap ingestion in each aphid during the 8-hour esperiment (Fig. 2). On caraway oil-treated plants, probing activities occupied $18 \%$ of experimental time and these activities were limited almost exclusively to probing in peripheral tissues: epidermis and mesophyll (99\% of probing 
time). The total probing time was divided into 15 plant penetrations that were 5.8 minutes long, on average. The non-probing periods were of relatively long duration, i.e. 26 minutes long. Phloem phase occupied less than 1\% of probing time and no sustained sap ingestion periods occurred during phloem phase (Tab. 1, Fig. 2). On carvone-treated plants, non-probing activities predominated (70\% of experimental time). Probing was related mainly to penetration of peripheral plant tissues ( $89 \%$ of probing activities). Probes were numerous (more than 30 in one individual, on average), shorter than 5 minutes, and divided by relatively long (at least $10 \mathrm{~min}$.) non-probing periods. Salivation into sieve elements occupied $23 \%$ of phloem phase and no sustained sap ingestion periods occurred (Tab. 1, Fig. 2). On limonene-treated plants, aphids spent more than $60 \%$ of experimental time on non-probing activities. A substantial part of probing (86\%) was pathway activities (i.e. probing in non-vascular tissues). There were 19 probes per aphid and the average duration of a probe was ca. 10 minutes. Phloem phase included long periods of watery salivation ( $20 \%$ of all activities during phloem phase) but several episodes of sustained sap ingestion also occurred (Tab. 1, Fig. 2).

Table 1. Summary of Myzus persicae activities during probing on plants treated with caraway oil and its major constituents: carvone and limonene

\begin{tabular}{|l|l|l|l|l|l|}
\hline EPG parameters & & $\begin{array}{l}\text { Control } \\
\mathrm{n}=11\end{array}$ & $\begin{array}{l}\text { Caraway oil } \\
\mathrm{n}=8\end{array}$ & $\begin{array}{l}\text { Carvone } \\
\mathrm{n}=13\end{array}$ & $\begin{array}{l}\text { Limonene } \\
\mathrm{n}=11\end{array}$ \\
\hline $\begin{array}{l}\text { Total duration } \\
\text { of non-probing }\end{array}$ & $\mathrm{h}$ & $\begin{array}{l}1.18 \\
( \pm 0.25)\end{array}$ & $6.55( \pm 0.35) * * *$ & $5.58( \pm 0.50) * * *$ & $5.02( \pm 0.83) * *$ \\
\hline $\begin{array}{l}\text { Total duration } \\
\text { of probing }\end{array}$ & $\mathrm{h}$ & $\begin{array}{l}6.82 \\
( \pm 0.25)\end{array}$ & $1.44( \pm 0.35) * * *$ & $2.42( \pm 0.50) * * *$ & $2.98( \pm 0.83) * *$ \\
\hline $\begin{array}{l}\text { Total duration } \\
\text { of pathway C }\end{array}$ & $\mathrm{h}$ & $\begin{array}{l}4.31 \\
( \pm 0.66)\end{array}$ & $1.43( \pm 0.35) * *$ & $2.15( \pm 0.47) *$ & $2.56( \pm 0.70)$ \\
\hline $\begin{array}{l}\text { Total duration } \\
\text { of xylem phase G }\end{array}$ & $\mathrm{h}$ & $\begin{array}{l}0.63 \\
( \pm 0.23)\end{array}$ & $0.0( \pm 0.0)$ & $0.05( \pm 0.03)$ & $0.15( \pm 0.11)$ \\
\hline $\begin{array}{l}\text { Total duration } \\
\text { of phloem phase } \mathrm{E}\end{array}$ & $\mathrm{h}$ & $\begin{array}{l}1.88 \\
( \pm 0.73)\end{array}$ & $0.02( \pm 0.02) *$ & $0.22( \pm 0.19)$ & $0.27( \pm 0.17)$ \\
\hline $\begin{array}{l}\text { Number of probes } \\
\text { Num }\end{array}$ & $\#$ & $25.8( \pm 5.3)$ & $15.0( \pm 15.0) * *$ & $31.2( \pm 6.0)$ & $19.2( \pm 6.1)$ \\
\hline $\begin{array}{l}\text { Proportion of phloem } \\
\text { phase in probing } \\
\text { activities }\end{array}$ & $\%$ & $26.4( \pm 9.5)$ & $0.9( \pm 0.9) *$ & $6.0( \pm 4.9)$ & $8.1( \pm 3.4)$ \\
\hline $\begin{array}{l}\text { Proportion } \\
\text { of salivation in } \\
\text { phloem phase }\end{array}$ & $\%$ & $15.8( \pm 9.2)$ & $12.5( \pm 12.5)$ & $22.7( \pm 10.7)$ & $19.9( \pm 9.8)$ \\
\hline
\end{tabular}


Values represent means $( \pm \mathrm{SE}), \mathrm{n}=$ number of aphids analyzed, asterisks indicate statistically significant differences in relation to control (Brassica rapa ssp. pekinensis): ${ }^{*} \mathrm{p}<0.05,{ }^{* *} \mathrm{p}<0.01,{ }^{* * *} \mathrm{p}<0.001$, Mann-Whitney U-test.

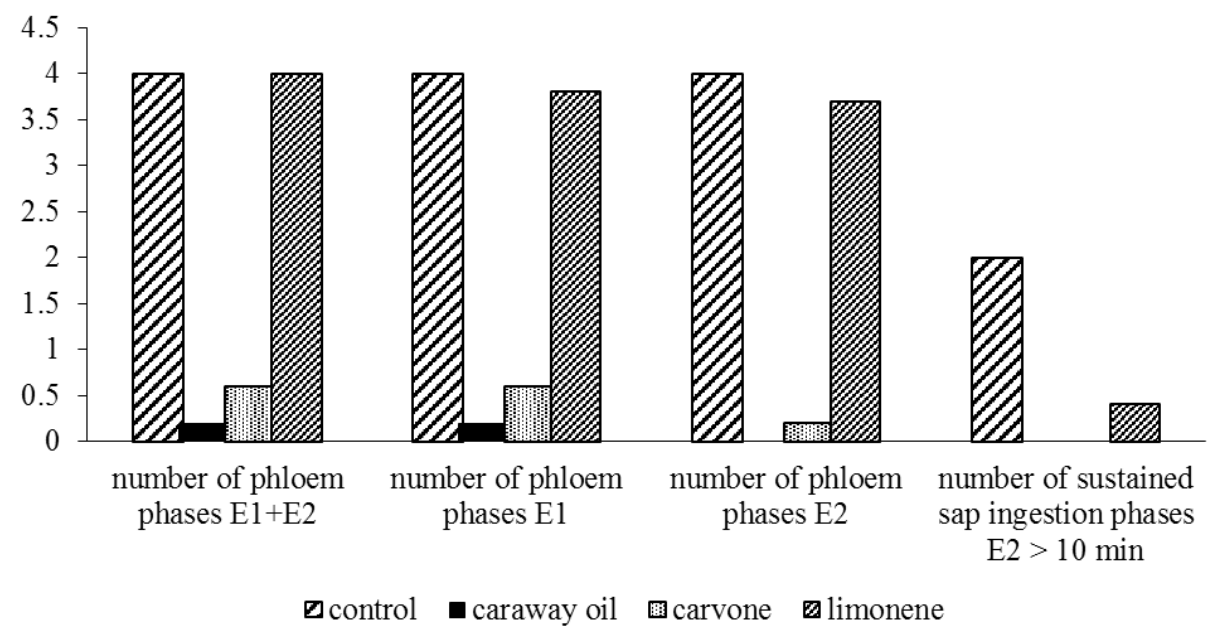

Figure 2. Occurrence of phloem phases in Myzus persicae during probing on plants treated with caraway oil and its major constituents: carvone and limonene

\section{Discussion}

The probing and feeding activities of aphids in the present study was monitored using the EPG (Electrical Penetration Graph) technique that provides a possibility to trace aphid stylet activities in plant tissues. The parameters describing aphid behavior during probing and feeding, such as total time of probing, number of probes, duration of phloem sap ingestion, duration of sap ingestion from one sieve element, etc. are good indicators of plant suitability or interference of probing by chemical or physical factors in particular plant tissues (Mayoral et al. 1996).

Generally, the results of the present research confirmed the strong and persistent deterrent effects of caraway essential oil towards $M$. persicae, which were reported in the former studies (Dancewicz et al. 2012). The aphid averseness to settle on caraway oil-treated plants that was observed in a choice-test (Dancewicz et al. 2012) was clearly a behavioral response following olfactory and gustatory contacts with the crude oil as well as its main components on plant surface and within plant tissues. In the present study, aphid activities related to probing were 
significantly reduced after the application of all substances studied: the caraway oil and chemically pure carvone and limonene. Probes in plant tisues, when present, were short. Their 5-6 min duration showed that aphid stylets did not reach beyond subepidermal layers of mesophyll. Before reaching the phloem vessels of host food plants, aphids ingest small samples of parenchyma cell contents for gustatory purposes (Martin et al. 1997). Gabryś and Tjallingii (2002) showed that aphids can distinguish a host from a non-host plant before reaching sieve elements. Short $(<10 \mathrm{~min})$ probes are limited either to the epidermis $(<2 \mathrm{~min}$; Van Hoof 1958) or do not reach beyond the mesophyll layer (2-10 min; Gabryś et al. 1997). Additionally to disturbances in aphid probing in non-vascular tissues, a significant reduction in the duration of phloem phase occurred in aphids on treated leaves that reached sieve elements in the present study. Moreover, a considerable portion of aphid activities in phloem vessels was watery salivation. Prolonged salivation is characteristic of aphid behavior on resistant plant cultivars or non-host plants (Van Helden, Tjallingii 1993; Wilkinson, Douglas 1998; Gabryś, Pawluk 1999). The effect of limonene application on aphid behavior was slightly weaker than that of crude oil and carvone. Although probing time was significantly shorter on limonene-treated plants than on control, the probes and phloem phase were slightly longer than on caraway oil- and carvone-treated plants, and sustained sap ingestion periods occurred, which was not the case on caraway oiland carvone-treated plants.

The withdrawal of stylets after having probed in peripheral tissues as well as in vascular bundle in the present study shows that caraway oil, carvone, and limonene, which were applied to the plant surface, have penetrated into the plant and were distributed systemically. Such phenomenon has also been found during other studies on aphid behavior-modifying natural and synthetic compounds (Gabryś et al. 2015).

\section{Conclusions}

Caraway essential oil and its main components: carvone and limonene are probing and feeding deterrents to M. persicae. Aphid behavior was modified at the level of non-vascular tissues as well as sieve elements: on treated plants, probes were short and non-probing intervals were long, phloem phase was short and sustained sap ingestion periods occurred sporadically. The deterrent activity of 
caraway oil is determined mainly by the content of carvone, which has the most significant impact on aphid probing behavior.

\section{References}

Abdelgaleil S.A.M., Mohamed M.I.E., Badawy M.E.I., El-arami S.A.A. 2009. Fumigant and contact toxicities of monoterpenes to Sitophilus oryzae (L.) and Tribolium castaneum (Herbst) and their inhibitory effects on acetylcholinesterase activity. Journal of Chemical Ecology, 35: 518-525.

Abd-Elhady H. 2012. Insecticidal activity and chemical composition of essential oil from Artemisia judaica 1. against Callosobruchus maculatus (f.) (Coleoptera: Bruchidae). Journal of Plant Protection Research, 52: 347-352.

Blackman R.L. Eastop V.F. 1985. Aphids on the World's Crops: An Identification Guide. John Wiley and Sons, Chichester-New York-Brisbane-Toronto-Singapore.

Bogdanowicz W., Chudwicka E., Filipiuk L., Skibińska E. 2004. Fauna Polski. Charakterystyka $i$ wykaz gatunków, Vol. I. Muzeum i Instytut Zoologii PAN, Warszawa.

Caballero-Gallardo K., Olivero-Verbel J., Stashenko E.E. 2011. Repellent activity of essential oils and some of their individual constituents against Tribolium castaneum Herbst. Journal of Agricultural and Food Chemistry, 59: 1690-1696.

Cichocka E. 1980. Mszyce roślin sadowniczych Polski. PWN, Warszawa.

Cichocka E., Goszczyński W. 1986. Biologia odżywiania i bezpośrednia szkodliwość mszyc. Zeszyty Problemowe Postępów Nauk Rolniczych, 329: 7-21.

Crowell P.L. 1999. Prevention and therapy of cancer by dietary monoterpenes. Journal of Nutrition, 129: 775S-778.

Dancewicz K., Gabryś B. 2008. Effect of extracts of garlic (Allium sativum L.), wormwood (Artemisia absinthium L.) and tansy (Tanaceum vulgare L.) on the behavior of the peach potato aphid Myzus persicae (Sulz.) during the settling on plants. Pesticydy, 3-4: 93-99.

Dancewicz K., Gabryś B., Halarewicz-Pacan M., Grabarczyk M., Wawrzeńczyk C. 2005. Effect of terpenoid lactones with di- and trimethylcyclohexane systems on the behavior of green peach aphid Myzus persicae. Pestycydy, 4: 17-23.

Dancewicz K., Kordan B., Szumny A., Gabryś B. 2012. Aphid behavior-modifying activity of essential oils from Lamiaceae and Apiaceae. Aphids and Other Homopterous Insects, 18: 93-100.

Dehghani F., Panjehshahin M.R., Vojdani Z. 2010. Effect of hydroalcoholic extract of caraway on thyroid gland structure and hormones in female rat. Iranian Journal of Veterinary Research, 11 (4): 337-341. 
Dutka A. 2013. Zastosowanie olejków eterycznych w ochronie roślin przed szkodnikami w świetle najnowszej literatury. Postępy w Ochronie Roślin, 53: 36-42.

Fang R., Jiang C.H, Wang X.Y., Zhang H.M., Liu Z.L., Zhou L., Du S.S., Deng Z.W. 2010. Insecticidal activity of essential oil of Carum carvi fruits from china and its main components against two grain storage insects. Molecules, 15: 9391-9402.

Gabryś B. 2000. Powiązania między owadami i roślinami - badania nad mechanizmami odporności roślin na żerowanie mszyc. Biotechnologia, 3 (50): 69-80.

Gabryś B., Pawluk M. 1999. Acceptability of different species of Brassicaceae as hosts for the cabbage aphid. Entomologia Experimentalis et Applicata, 91: 105-109.

Gabryś B., Tjallingii W.F., Van Beek T. 1997. Analysis of EPG recorded probing by cabbage aphid on host plant parts with different glucosinolate contents. Journal of Chemical Ecology, 23: 1661-1673.

Gabryś B., Dancewicz K., Gliszczyńska A., Kordan B., Wawrzeńczyk C. 2015. Systemic deterrence of aphid probing and feeding by $\beta$-damascone analogues. Journal of Pest Science, 88: 507-516.

Hoof H.A., van. 1958. An investigation of the biological transmission of a non-persistent virus. The Agricultural University, Wageningen.

Kaefer C.M., Milner J.A. 2011. Herbs and Spices in Cancer Prevention and Treatment. In: Herbal Medicine: Biomolecular and Clinical Aspects. I.F.F. Benzie, S. WachtelGalor (eds.). 2nd edition. CRC Press, Boca Raton.

Keshavarz A., Minaiyan M., Ghannadi A., Mahzouni P. 2013. Effects of Carum carvi L. (Caraway) extract and essential oil on TNBS-induced colitis in rats. Res. Pharm. Sci., 8: 1-8.

Koul O., Walia S., Dhaliwal G. 2008. Essential Oils as Green Pesticides: Potential and Constraints. Biopesticides International, 4: 63-84.

Leszczyński, B. 1996. Kurs praktyczny w zakresie chemicznych interakcji owady - rośliny na przykładzie mszyc Aphidodea. Wyższa Szkoła Rolno-Pedagogiczna, Siedlce.

Martin B., Collar J.L., Tjallingii W.F., Fereres A. 1997. Intracellular ingestion and salivation by aphids may cause the acquisition and inoculation of non-persistently transmitted plant viruses. Journal of General Virology, 78: 2701-2705.

Mayoral A.M., Tjallingii W.F., Castanera P. 1996. Probing behavior of Diuraphis noxia on five cereal species with different hydroxyamic acid levels. Entomologia Experimentalis et Applicata, 78: 341-348.

Pettersson J., Tjallingii W.F., Hardie J. 2007. Host-plant selection and feeding. In: Aphids as crop pests. H.F. van Emden, R. Harrington (eds). CABI, Wallingford, pp. 87-113.

Samojlik I., Daković-Švajcer K., Božin B., Mikov M. 2012. Herb-drug interactions: the influence of essential oil of caraway (Carum carvi L.) on the pharmacokinetics of paracetamol. BMC Pharmacology and Toxicology, 13 (Suppl. 1): A27. 
Sedláková J., Kocourková B., Lojková L., Kubán̆ V. 2003. The essential oil content in caraway species (Carum carvi L.). Horticultural Science, 30: 73-79.

Seidler-Łożykowska K., Król D., Bocianowski J. 2010. Zawartość olejku eterycznego i jego skład w owocach pochodzących z kolekcji kminku zwyczajnego (Carum carvi L.). Rośliny oleiste - Oilseed crops, XXXI-1, 145-158.

Szumny A., Figiel A., Gutierrez-Ortiz A., Carbonell-Barrachina A.A. 2010. Composition of rosemary essential oil (Rosmarinus officinalis) as affected by drying method. Journal of Food Engineering, 97: 253-260.

Tjallingii W.F. 1995. Electrical signals from the depths of plant tissues: the electrical penetration graph (EPG). In: Proceedings of IFS Workshop in Chemical Ecology. H. Niemeyer (ed.). Santiago, Chile, pp. 48-58.

Tjallingii, W. 2001. Plant penetration by aphids as revealed by electrical penetration graphs. Aphids and Other Homopterous Insects, 8: 105-120.

Van Helden M., Tjallingii W.F. 1993. Tissue localisation of lettuce resistance to the aphid Nasonovia ribisnigri using electrical penetration graphs. Entomologia Experimentalis et Applicata, 68: 269-278.

Wilkinson T.L., Douglas A.E. 1998. Plant penetration by pea aphids (Acyrthosiphon pisum) of different plant range. Entomologia Experimentalis et Applicata, 87: 43-50.

Zheng G.Q., Kenney P.M., Lam L.K. 1992. Anethofuran, carvone, and limonene: Potential cancer chemopreventive agents from dill weed oil and caraway oil. Planta Medica, 58: $338-341$.

\section{W POSZUKIWANIU BIOPESTYCYDÓW: WPLYW OLEJKU ETERYCZNEGO Z KMINKU CARUM CARVI I JEGO GŁÓWNYCH SKLADNIKÓW NA ZACHOWANIE MSZYCY BRZOSKWINIOWEJ MYZUS PERSICAE PODCZAS PENETRACJI ROŚLIN}

\section{Streszczenie}

Zastosowanie olejku eterycznego kminku oraz jego głównych składników, karwonu i limonenu, spowodowało znaczące zmiany w zachowaniu mszyc podczas penetracji zarówno pozafloemowych tkanek roślinnych, jak i rurek sitowych. Na traktowanych roślinach nakłucia tkanek były krótkie i przedzielone długimi okresami braku penetracji. Okresy żerowania występowały sporadycznie. Stwierdzono, że deterentne działanie olejku kminkowego spowodowane jest głównie przez zawartość karwonu, który miał najistotniejszy wpływ na zachowanie mszyc. Zahamowanie penetracji roślin na etapie 
tkanek pozawaskularnych i elementów floemu świadczy o możliwości przenikania badanych substancji przez powierzchnię roślin i ich dystrybucję na drodze systemicznej.

Słowa kluczowe: antyfidanty, olejki eteryczne, kminek, elektroniczna rejestracja żerowania mszyc

Cite this article as: Wróblewska-Kurdyk A., Nowak L., Dancewicz K., Szumny A., Gabryś B. 2015. In search of biopesticides: the effect of caraway Carum carvi essential oil and its major constituents on peach potato aphid Myzus persicae probing behavior. Acta Biologica, 22: 51-62. 